\author{
AnNa RudaKowsKa \\ Tamkang University \\ ORCID ID: https://orcid.org/0000-0002-5107-5788
}

\title{
Taiwanese Attitudes toward the Political Newcomers in 2016
}

\section{Taiwanese Attitudes toward the Political Newcomers in 2016}

\section{Abstract}

Taiwan's Legislative Yuan (LY) is commonly seen as an institution comprised of career politicians. In fact, candidates without prior experience in elected seats of the island's political structures are no strangers to the LY. Moreover, in the 2016 parliamentary elections, the political novices enjoyed unprecedented support and achieved relative success. The New Power Party (NPP), which only formed in early 2015 and popular mainly due to the several debutants it fielded, including Freddy Lim, Hung Tzu-yung and Huang Kuo-chang, emerged as the LY's third-largest party. Although it garnered only five of the 113 seats $(4.4 \%)$, it was a great win for the fledgling party, ranking it third behind the Kuomintang (KMT) and the Democratic Progressive Party (DPP), which have reigned over the island's political scene for the past several decades.

This article examines the phenomenon of Taiwanese novices. It looks at them from the voters' perspective. It surveys the demographic profiles and political preferences of Taiwanese who support the newcomers' engagement in the political process, and compares them with citizens who express negative attitudes toward the newcomers.

Keywords: Taiwan, newcomers, personal stories, political communication, elections 2016 


\section{Тайваньское отношение к политическим новичкам в 2016 году}

\section{Аннотачия}

Законодательный Юань Тайваня (LY) обычно рассматривается как институт, состоящий из профессиональных политиков. На самом деле, ему не чужды кандидаты без предшествующего опыта работы на выборных местах в политических структурах острова. Более того, на парламентских выборах 2016 года политические новички получили беспрецедентную поддержку и достигли относительных успехов. Партия «Новая сила» (NPP), образованная лишь в начале 2015 года и популярная в основном благодаря нескольким дебютантам на политической сцене, включая Фредди Лима, Хун Цзы-юнга и Хуан Го-чан, стала третьей по величине партией ЛЮ. Хотя она получила только пять из 113 мест $(4,4 \%)$, это была отличная победа для молодой партии, которая заняла третье место после Гоминьдана (KMT) и Демократической прогрессивной партии (DPP), которые доминировали на политической сцене острова в течение последних нескольких десятилетий.

В данной статье рассматривается феномен тайваньских новичков, которая рассматривает его с точки зрения избирателей. В ней анализируются демографические характеристики и политические предпочтения тайваньцев, поддерживающих участие новичков в политическом процессе, а также проводится их сравнение с гражданами, которые негативно относятся к дебютантам.

Ключевые слова: Тайвань, новички, личные истории, политическое общение, выборы 2016

\section{Introduction - Taiwan 2016 elections}

Taiwan's 2016 elections brought about a victory not only for the Democratic Progressive Party (DPP, Minjindang 民進黨) $)^{1}$, which secured a majority in the legislature, and its presidential candidate Tsai Ing-wen 蔡英文, but also for several debutants on the political stage, including Freddy Lim 林昶佐, Hung Tzu-yung 洪慈庸, Huang Kuo-chang 黃國昌 and their recently established (early 2015) New Power Party (NPP, Shidai Liliang 時代力量) ${ }^{2}$.

1 The study transcribes Chinese terms and names using Hanyu Pinyin without tone markers. The exception to this rule are Chinese names, which are transcribed according to each individual's preferred romanization, or proper names that are conventionally rendered, officially established, or often appear in the media in forms other than Pinyin (e.g., "Tsai ling-wen," “Taipei”, etc.).

2 On 16 January 2016, Taiwanese voted to elect the nation's $14^{\text {th }}$ president, vice president, and 113 members of the $9^{\text {th }}$ Legislative Yuan (LY). Taiwan's presidential and vice-presidential 
The NPP emerged as Taiwan's third-largest political party in the Legislative Yuan (LY, Lifayuan 立法院). Although it garnered only five of the 113 seats (4.4\%), it was a great win for the fledgling party, ranking it third behind the Kuomintang (KMT, Guomindang 國民黨) and the DPP, which have reigned over the island's political scene for the past several decades.

Given the specificity of Taiwan's political environment, the debutants' spectacular success seems even more puzzling. Firstly, the island's electoral system discriminates against the small start-up parties (Fell, 2005, 2006, 2014; Jou, 2009; Schafferer, 2003), in which newcomers often gain in political prominence (Barr, 2009). Secondly, in the national elections, both presidential and legislative, partisan rather than personal factors have a greater impact on citizens' voting decisions (Batto, 2013). Therefore, a great number of politicians, particularly those from the two parties dominating the island's political stage - the KMT and DPP, can secure seats in the LY by simply relying on the party label, with personal appeal playing a secondary role.

This success of the political debutants, who do not owe their electoral victories to affiliation with either of the dominant parties, but some of whom represent a newly established ones, makes the phenomenon worth attention ${ }^{3}$. This study examines the newcomers to Taiwan's politics. It defines newcomers as the candidates, who, despite their non-political backgrounds - e.g. in medicine, entertainment, or business - have been elected to some of their respective countries' highest political positions in the legislature or presidency.

candidates are running on the same ticket and are selected according to the first-past-the-post method (FPTP). The three presidential candidates were: Tsai Ing-wen of the Democratic Progressive Party (DPP), Eric Chu of the Kuomintang (KMT), and James Soong, the candidate of the People First Party (PFP). In the legislative ballot, the 113 seats are filled in in three ways: 73 legislators represent geographical constituencies, which are single-member districts (SMDs); 6 seats are reserved for the indigenous populations, and the remaining 34 legislators are selected using a nationwide proportional representation party-list system (PR) (Rich, 2014). Parties must receive at least $5 \%$ of votes nationwide to gain PR seats, which constitutes a disadvantage for small parties (Jou 2009, p. 762), particularly new ones. The main players in the legislative elections were the KMT and DPP, nominating 110 and 96 candidates respectively, competing along with a number of small parties.

3 In the 2016 elections, the DPP was willing to work with the NPP. According to some commentators, this cooperation might have given a green light to some of the supporters of the DPP or Pan-Green Camp to vote for NPP candidates. Therefore, the influence of partisan factors on the popularity of the NPP candidates cannot be excluded. 


\section{Novices in the Literature}

Political novices around the world, particularly in the United States, Latin America and the United Kingdom, constitute a well-examined theme. The classic and one of the most comprehensive studies of the topic by David T. Cameron (2009) anlyzes the United States Congress. He writes about "political amateurs" who won elections with no previous experience. Leuthold (1968) and Kazee (1980), define political debutants in a similar manner and underscore their role as challengers to incumbents in congressional elections. This understanding of novices has been the most popular in the literature, particularly in the studies focusing on a phenomenon of an individual debutant. The political novice may be a businessperson, celebrity or academic - e.g., Alberto Fujimori, Ross Perot, Jesse Ventura, or Arnold Schwarzenegger - who succeeded in politics, despite having no prior political experience (Ellner, 2003; Ferguson, 2016; Ostiguy \& Roberts, 2016; Schulte-Sasse, 1993; Seltzer, 2016; Thimsen, 2010). Or he may be, as in the most recent works, Donald Trump, the first United States president with no prior experience in governance (Fuchsmann, 2017; Pinkerton, 2016). Another is Paweł Kukiz, an actor and singer who ran for president in Poland, receiving $21 \%$ of the vote in the first round of elections (Boguszewski, 2015; Pankowski, 2015). However, Wilson (1962) proposes a different understanding of the phenomenon. In the study on novices in the US politics, instead of focusing on novelty, he distinguished amateurs from professional or conventional politicians based on ideology and claimed that while the former acts in the public interest, the latter realizes party goals and is motivated by material incentives. Moreover, the term "novice" is used in the literature interchangeably with "outsider" to underscore the politicians' status as newcomers to the established party system (Barr, 2009; Bunker \& Navia, 2013). Still, the label "outsider" is not always synonymous with "novice" as it may also carry meanings unrelated to novelty, as in the case of experienced political independents. In his study of Margaret Thatcher, King (2002) pointed out to another type of outsider, manifested in the rhetoric of politicians who wish to underscore their ideological novelty or opposition to the ruling party or prevailing political or economic trends. Finally, there are studies, which conflate novices with populist politicians (Barr, 2003; Ellner, 2003). This lack of agreement on what defines a political 
novice is, to a significant degree, related to the differences in the political cultures and systems of the countries in question. Therefore, the findings on novices in other parts of the world do not correspond to the realities of Taiwan's political arena.

Despite their recent electoral successes and the fact that there is nothing unusual about their presence in the legislature, Taiwan's political newcomers have been overlooked in academia ${ }^{4}$. The initial, and thus far the only, research focused solely on political novices in Taiwan (Rudakowska \& Trojnar, 2016) aimed to fill that gap by analyzing popular understanding of the debutants' and their success. The study found that Taiwanese mainly perceive novices as outsiders to the political system. The factor mainly responsible for this view is the novices' inexperience and the prevailing conviction that they are better suited to represent ordinary citizens than career politicians, who tend to lose touch with the needs of the masses they serve. The same study also found that time in office is not a decisive factor in perceptions of novelty since Taiwanese recognized as novices those who had just started their political careers, as well as those with more than one year of experience. Although the study provided essential insights into Taiwanese understanding of political novices, it also left important questions unanswered and called for further research on the topic. First, it noted that the popularity of all four of the island's most recognized political newcomers stems from their distinct personal stories, which are known to nearly all in society. This conclusion suggests that even if partisan factors dominate Taiwanese voters' choices of national legislators, in the case of the newcomers, certain personal factors contribute greatly to their popularity and play an important role in their electoral fate. The popularity of these stories in Taiwan, coupled with recent

4 According to the estimates made by the CommonWealth (Tianxia Zazhi 天下雜誌) journalist Lin Xing-fei, 47 members of the $9^{\text {th }}$ LY were elected to the office of parliamentarian for the first time. See: Lin Xing-fei, “The Parliament turns from blue to green. How is the DPP going to start the reform?” CommonWealth, 19 January 2016, http://www.cw.com.tw/ article/article.action?id=5074011 (accessed 20 September 2017). According to the author's own calculation based on the data concerning the members of the LY provided on the ROC's official LY website, 32 out of 113 members of the $9^{\text {th }}$ LY (not including the members who resigned) were political novices who had not held any elected political office. See: http:// www.ly.gov.tw/03_leg/0301_main/legList.action (accessed 20 September 2017). 
findings in the area of political communication, suggests that the demand for newcomers with personal stories may grow in the island's politics in the future as a part of global political trends ${ }^{5}$. This prediction makes research on the topic even more urgent. Second, the same study found that the majority of Taiwanese $(60 \%)$ held a positive view of the newcomers, with a disapproval rate of only 19\%; however, it did not inquire into the differences in attitudes among the various cohorts.

Therefore, to contribute to the understanding of newcomers on the Taiwanese political scene, this study starts with a closer examination of their personal stories, followed by a detailed analysis of voters' attitudes toward the newcomers. To determine which voters are more likely to prefer political newcomers, the investigation examines respondents' social profiles as well.

\section{Methodology}

The literature looks at the novices from at least two distinct perspectives. The first focuses on the politicians themselves. It examines debutants as sources of agendas and discourses and investigates their parties, including the parties' location in the system and arrangement of their relationship

5 The studies on political communication, particularly on the personalization of politics, discuss the growing demand for personal stories among voters around the world. The sources of these changes are traced to the behavior of citizens, politicians, and the media. Mancini and Swanson (1996) argue that modernization led to the disintegration of traditional social structures, producing a demand for new paradigms to fill the vacuum. They suggest that citizens need "symbolic realities," such as "symbolic templates of heroes and villains, honoured values and aspirations, histories, mythologies, and self-definition" (Mancini \& Swanson 1996, p. 9). In response to this demand, governments, political parties and individual politicians seek to provide such "symbolic realities," mostly in the form of politicians' personal stories (hence "personalization"), which have become the central feature of new political communication. In personalizing, they draw on the conventions, resources and skills of popular culture, advertising, show business and the world of celebrity (Marshall, 1997; Meyer, 2002). Moreover, political actors have become more adept at using media for their own purposes, leaving nothing to chance, treating political communication as a form of advertising (Jamieson, 1984). As a result, politics has become a media performance in which the creation of political personalities plays a crucial role. Both tendencies - the demand for personal stories and the responses of politicians who use new techniques to provide them - are reinforced by mass media, as its conventions favour personal stories (Mancini \& Swanson, 1996; Berry \& Sobieraj, 2016; Mutz, 2015). 
with the electorate. For instance, Barr (2009), who differentiates the terms which are often conflated in the literature - political outsiders, novices, anti-establishment politicians and populists - analyzes three factors that distinguish newcomers. He studies a political discourse constructed to build support, the location of politicians in the party system and the way parties arrange their relationship with the citizens. The second group of studies investigates the novices from the voters' point of view. They are mostly interested in the factors standing behind the debutant's success and examine the changes in voters' ideological identification and regime-related preferences (Bunker \& Navia, 2013; Dugas, 2003; Murillo, Vaishnav \& Oliveros, 2009). These studies demonstrate that the "novice" label can be enabling, as well as limiting to newcomers' political fortunes, depending on the circumstances. For example, by virtue of being in office, incumbent politicians get much more publicity than newcomers, and as a result, have an advantage over rookie challengers. At the same time, the research shows that in certain circumstances, such as growing inflation or increasing unemployment, voters from industrialized countries may punish incumbents for their underperformance and turn to novices (Duch \& Stevenson, 2008). What both approaches have in common is that the authors a priori decide whom they name as political newcomers.

This study looks at the newcomers from two perspectives. First, it examines politicians themselves, particularly their personal stories. This provides the context for the second part, which, in order to inquire into Taiwanese society's varied attitudes toward the newcomers, takes voters' perspectives. However, in contrast to the prevailing literature, it does not take for granted the question of who may be considered, a political newcomer. Instead, it allows voters to name and assess the novices. It avails itself of telephone interviews with people of voting age in the Taiwan area conducted by the National Chengchi University's Election Study Centre (政治大學選舉研 究中心) from 10 to 17 March 2016. The interviewers asked 31 substantive questions, as well as questions about socio-demographic characteristics, obtaining 1722 valid samples. With a 95\% confidence level, the survey has a margin of error $\pm 2.36 \%$. This study avails itself ten of the survey questions, which are listed in the Appendix. 
At the same time, a survey's choice of words can influence respondents' answers; therefore, it is important to add that the survey was conducted in Chinese and used the term zhengzhi suren 政治素人 for “political newcomer(s).” The term refers to the people, who, despite having non-political backgrounds, get elected to the country's highest political positions.

\section{Findings}

In general Taiwanese see novices in a positive light (61.5\% of respondents), and only $19.9 \%$ described their impact as negative. 18.6\% (1059, 342 and 321 respectively out of a total 1722 valid responses) did not respond to this question ${ }^{6}$. The presents an examination of factors that may help in differentiating between the voters who had positive views of novice and those with negative views without considering the $18.6 \%$ those who did not respond.

\section{What personal stories?}

In an answer to the open survey question asking respondents to give up to three political newcomers (Appendix, Question 2), 89.4\% of survey responses in the first place named only four individuals: Hung Tzu-yung, Ko Wen-je, Freddy Lim and Huang Kuo-chang (90.5\% in second place and $88.2 \%$ in the third place; the novices are listed in order, from the most to least often mentioned individuals). Three of these politicians - Hung, Lim and Huang ran for election in 2016 as NPP candidates, defeating KMT candidates, while Ko ran for Taipei City mayor in 2014 as an independent whose strongest competitor was also a KMT politician. These neophytes share one common characteristic - before the elections, all of them, despite having no prior experience in elected office, enjoyed island-wide recognition thanks to their personal stories. Yet, these stories, which undoubtedly contributed to their political successes, substantially differ from each other.

6 This study uses the data from the same survey as the previous research on political newcomers in Taiwan by Rudakowska \& Trojnar. The small differences in numbers between the two works stem from the fact that the previous study was based on weighted data, while this one included non-weighted data. 
Hung Tzu-yung gained national recognition in 2013 after her brother - Hung Chung-chiu 洪仲丘, an army corporal, died following strenuous exercise drills. This event triggered protests and a demand for greater transparency in military investigations. Acting as the family spokesperson, Hung Tzu-yung played a leading role in the protests, which ignited a civil movement demanding human rights in the military ${ }^{7}$. Even today, 57 out of 589 respondents who identified Hung Tzu-yung as a political novice (9.68\%) referred to her as Hung Chung-chiu's sister or "the one whose younger brother died in the military" instead of using her name. Hung underscores her outsider's status by distancing herself from traditional politicians. She stresses her "ordinary' background and claims that politics had always been "extremely distant" from her family to the degree that she "couldn't understand it, let alone actively participate in it". She drew close to the young people engaged in civil movements, particularly the 2014 Sunflower Movement (Taiyanghua Yundong 太陽花運動), a protest led by students and civic groups opposing the Cross-Strait Service Trade Agreement (CSSTA), as well as non-partisans tired of the competition between the two main Taiwanese parties. Hung explained that her choice of the NPP as the political platform gave her more freedom to make her own decisions and create new rules instead of being bound by norms created by others, as would have been the case had she joined the DPP. Moreover, Hung points to the "quest for justice" as the main factor behind her decision to compete for a seat in legislature'. Therefore, she positioned herself as a defender of justice not only on behalf of her brother but for all the Taiwanese who might encounter unjust treatment due to inadequate rules and laws.

7 Li Wen, "NPP nominates political novice," Taipei Times, 25 February 2015, http://www. taipeitimes.com/News/taiwan/archives/2015/02/25/2003612201 (accessed 25 April 2016).

8 "I am Hung Tzu-yung (洪慈庸). I grew up in an ordinary, warm family. I had always thought that politics was extremely distant from me. I couldn't understand it, let alone actively participate in it.' New Power Party's Facebook page, available at: https://www.facebook.com/newpowerparty/photos/a.891139534290737/914760548595302/?type=1\&theater (accessed 25 December 2018).

9 New Power Party's Facebook page, available at: https://www.facebook.com/newpowerparty/photos/a.891139534290737/914760548595302/?type=1\&theater $($ accessed 25 December 2018). 
Ko Wen-je was a doctor with no previous experience in politics when he was elected Taipei City mayor in 2014. However, he had already made headlines in 1994 by supporting Chen Shui-bian's candidacy in that year's Taipei mayoral race. He stepped into the spotlight again in June 2012, heading a medical team that examined the then imprisoned ex-president, demanding Chen's release from his 20-year sentence for corruption on the grounds of deteriorating health. Finally, after winning election as the capital's mayor in 2014, he became one of Taiwan's most recognized politicians, mainly due to his personal charisma, style, and image as a political novice and outsider ${ }^{10}$. He branded himself a non-traditional politician, mostly due to his earnestness and gaffes, as well as his behavior, which underlined his unique political style. For example, he took part in a cross-country bike ride, rode the subway to work, and, most recently, recorded a hip-hop music video for his 2018 election campaign, all of which strengthened the public's perception of him as a political outsider. This image drew the support of many young people, including activists in post-Sunflower civil society. During the 2014 race, the DPP backed his candidacy, and Ko himself was regarded as leaning toward Taiwan independence ${ }^{11}$. Moreover, as an independent candidate, he proclaimed the dawn of non-partisan politics in the Taipei government, targeting nonpartisan voters ${ }^{12}$ and those looking "beyond blue and green."

Freddy Lim became popular particularly among the young generation of Taiwanese as the leading vocalist of the death-metal band Chthonic. He politically active before becoming one of the founding leaders of the NPP and winning a seat in the LY. He took advantage of his recognition as a singer to advocate human rights through various channels, for example, organizing music festivals for free Tibet, supporting civil society movements, such as the Sunflower Movement, or expressing political ideas in his

10 https://www.taiwannews.com.tw/en/news/3627819

11 However, Ko distanced himself from the DPP's position on Cross-Strait relations, and when he was re-elected as Taipei City mayor in 2018, his views on those issues were closer to the KMT position.

12 Percentages of voters identifying as nonpartisan in Taiwan have grown since 2011, reaching $38 \%$ by the time of Ko's first election in 2014 and exceeding $50 \%$ in 2017. 
lyrics ${ }^{13}$. A lot of Chthonic's lyrics look back on Taiwanese history and touch on political themes, such as the song "Broken Jade" or the album Bu-Tik. The former tells the story of World War II Taiwanese kamikaze pilots, who, after being recruited by the Japanese army, take part in suicide attacks on Allied vessels. In the words of the Chthonic bassist Doris Yeh, the latter "is all about violent events that have happened throughout Taiwanese history," addressing, for example, the 228 Incident - an anti-KMT uprising - and the White Terror that followed in its wake ${ }^{14}$. Lim explains that he uses songs to tell people stories, which "were once intentionally kept from the public in Taiwan and are now slowly being forgotten by many in mainstream society ${ }^{15}$. As a result of this political activism, Chthonic was banned from performing in China after Lim called Taiwan his "mother country" at the 2002 Golden Melody Awards. Lim has made clear his political views, including those on Taiwan independence. For example, in a CNN interview, he expressed the hope "that Taiwan can be more independent from the mainland, both economically and politically. Maybe Taiwan can trade more with other countries"16. Moreover, Lim chaired Amnesty International Taiwan in 2010-2014 ${ }^{17}$.

Huang Kuo-chang, the fourth most popular political newcomer, worked as a legal scholar at Academia Sinica, the nation's leading research institution, before entering the parliamentary race in January 2016. Before securing a seat in the LY in 2016, he had been very active in civil society movements. He initially won recognition for taking part in 2012's Anti-Media Monopoly Movement (Fan Meiti Longduan Yundong 反媒體壟斷運動), gaining greater

13 B. Hioe (2019) Interview: Freddy Lim, Daybreak, available at: https://daybreak. newbloommag.net/2019/03/19/interview-freddy-lim/, last visited: 15 April 2019.

14 Ghost Cult website, Raymond Westland, posted by Keefy, A Touch of History - An interview with Chthonic (20 July 2013) http://www.ghostcultmag.com/a-touch -of-history-an-interview-with-chthonic/

15 [這些故事是在台灣有一段時間是刻意不被人家知道, 到了現在它慢慢已 經跟主流社會的故事也已經脫節了] In: Brave Words website, 'Chthonic’s Freddy Lim reveals the story behind "Broken Jade”, 8 December 2011, http://bravewords.com/news/ chthonics-freddy-lim-reveals-the-story-behind-broken-jade-video-posted

16 https://edition.cnn.com/2016/01/13/asia/taiwan-rock-star-politician-freddy-lim/ index.html

17 Taipei Times (2015), op. cit. 
fame as a social activist for his leading role in the March 2014 Sunflower Movement protests ${ }^{18}$. In 2015, he joined the NPP and served as its chairman at the beginning same year. He had advocated the creation of a "third force" party aimed at satisfying "civil society's calls for reform", which the DPP and KMT had not responded to ${ }^{19}$. As a proponent of a "third force", he was much more critical of the KMT's policies, admitting to having "some shared values" with the DPP. After he was subjected to a recall election in 2019, Huang stepped down from the leader's position, even though votes calling for his ouster had fallen short of the required threshold.

Next, to get deeper understanding of the voters' attitudes toward these politicians, the study surveyed the demographic profiles (gender, age and occupation) and political preferences of the voters (i.e. political leanings, levels of satisfaction with domestic political parties when it comes to solving important social problems, concern for young people, opinions on citizen participation in politics, and their views on democracy) to gain a deeper understanding of the positive and negative attitudes towards newcomers among Taiwanese voters. The survey questions are shown in the Appendix.

Hung, Ko, Lim and Huang's personal stories, as well as the previous literature on the topic, provide important clues to the demographic profiles and political preferences of the newcomers' supporters. All the four newbies were very popular among the young supporters of the Sunflower Student Movement. Hung, Lim and Huang's party, the NPP, has its roots in this movement and Huang was one of its most active leaders. Additionally, young people are relatively less conservative than the other social groups (Tsai, 2016, p. 3) and may be more willing to embrace the unconventional politicians. Therefore, this study hypothesizes that young respondents and students exhibit more positive attitudes toward the newcomers. This should be consistent with the previous research on the topic, which found that $48 \%$ of the voters supporting political novices were students. Additionally, the close reciprocal relationship

18 Initium Media 端傳媒記者 林怡廷 發自台北 2015-08-27, 黃國昌：「台灣需要一 個新的本土政黨」(Huang Kuo-chang: Taiwan Needs a New Indigenous Party), available at: https://theinitium.com/article/20150827-taiwan-newpowerparty/

19 New Bloom, Radical Perspectives on Taiwan and the Asia Pacific (2015) Interview with Huang Kuo-chang by Brian Hioe (6 August), available at: https://newbloommag. net/2015/10/14/huang-kuo-chang-en/. 
between Sunflower Student Movement activists and the four newcomers suggests that respondents advocating increased citizen participation in politics would be more welcoming of newcomers than would those who favor leaving political matters in the hands of career politicians. Understanding the link between citizens' attitudes toward political involvement and preferences toward newcomers is crucial for the comprehension of recent changes on the Taiwanese political stage. Hsiao (2016) characterized these changes as a "new era of political development" in which "vibrant civil society" and its social and political movements had a significant impact on the 2016 elections. Testing this hypothesis tell us whether the activist segment of Taiwanese society supports the newcomers or is their political success unrelated to that trend. Moreover, the novices were deemed to be "beyond blue and green" political divisions (Ko) or announced the advent "third force" (Hung, Lim, and Huang) or a "white force" (Ko). This indicated a departure from the politics of the two main parties and a trend among dissatisfied voters to see newcomers as potential game-changers. These findings imply that citizens who are more dissatisfied with the main political parties and the level of attention those parties have given to young people's problems tend to be more positive about the newcomers' impact than voters who are satisfied with the main parties. This hypothesis is consistent with the findings from the research on Poland's 2015 presidential elections, the part of the electorate that voted for the newcomers explained their decision with the reference to the broadly understood idea of "change" (Pankowski, 2015). Lastly, this study analyzes the link between respondents' opinions of two political systems democracy and autocracy. Findings indicate that the Pan-Green backers are more supportive of the newcomers than the portion of the electorate that leans toward the Pan-Blue camp, as the four novices most often mentioned by the Taiwanese respondents are all closely associated with the former. We hypothesize that newcomers' supporters not necessarily see democracy as the best system, since political debutants are very often seen as various types of outsiders, as well as outsiders to the political system, who may challenge it (Barr, 2009). Testing these hypotheses brings us closer to understanding Taiwanese voters' attitudes toward the political novices. 


\section{Perception of political newcomers and their recognition in a society}

The respondents who pointed out to the four political novices most often mentioned in a response to an open question with one to three possible answers ("Who would you consider a political newcomer?"), largely hold positive views of newcomers. Eighty percent of those who mentioned any of the four politicians in the first place and $80.5 \%$ of those who mentioned them at least once in all the three answers expressed favorable opinions of novices in general (Table 1). Similarly, the respondents who named persons other than the four newcomers most often mentioned were mostly positive toward the newcomers (73.4\% expressed positive attitudes toward newcomers). Still, the answers to this question differ depending on which politician respondents named as the first. The most supportive of newcomers were those who as the first newcomer named Ko $(84.9 \%$ of these respondents expressed positive attitudes toward newcomers and only $15.1 \%$ held negative views) and the least supportive were those who as the first newcomer named Huang (64.7\% expressed positive versus $35.3 \%$ holding negative view of newcomers). The differences are not so pronounced when we look at all the answers to this question (Table 1, Q2.2) and oscillate between the highest support for the newcomers among those who referred to Ko $(84.2 \%)$, followed by Huang (80.2\%), and the lowest for Lim and Hung $(78.7 \%$ and $78.3 \%$ respectively).

Table 1. Taiwanese perspective on newcomers' participation in politics

\begin{tabular}{|c|c|c|c|c|c|}
\hline \multirow{2}{*}{$\begin{array}{l}\text { 1. Perspective on the newcomers' partici- } \\
\text { pation in politics }\end{array}$} & \multicolumn{2}{|c|}{$\begin{array}{l}\text { a) Positive } \\
\text { Frequency (\%) }\end{array}$} & \multicolumn{2}{|c|}{$\begin{array}{l}\text { b) Negative } \\
\text { Frequency (\%) }\end{array}$} & \multirow{2}{*}{$\begin{array}{c}\begin{array}{c}\text { a) }+\mathbf{b}) \\
\text { Frequency } \\
(\mathbf{1 0 0} \%)\end{array} \\
1401\end{array}$} \\
\hline & 1059 & $(75.6)$ & 342 & $(24.4)$ & \\
\hline \multicolumn{6}{|c|}{$\begin{array}{l}2.1 \text { Pointed to one of the following political newcomers (in the } 1^{\text {st }} \text { place) } \\
\text { A) The four most often mentioned newcomers: }\end{array}$} \\
\hline Hung Tzu-yung & 245 & $(75.9)$ & 78 & $(24.1)$ & 323 \\
\hline Ko Wen-je & 361 & $(84.9)$ & 64 & $(15.1)$ & 425 \\
\hline Freddy Lim & 72 & $(77.4)$ & 21 & $(22.6)$ & 93 \\
\hline \multirow[t]{2}{*}{ Huang Kuo-chang } & 22 & $(64.7)$ & 12 & $(35.3)$ & 34 \\
\hline & 700 & $(80)$ & 175 & $(20)$ & 875 \\
\hline B) Other newcomers & 80 & $(73.4)$ & 29 & $(26.6)$ & 109 \\
\hline
\end{tabular}




\begin{tabular}{|c|c|c|c|c|c|}
\hline & \multicolumn{2}{|c|}{$\begin{array}{l}\text { a) Positive } \\
\text { Frequency (\%) }\end{array}$} & \multicolumn{2}{|c|}{$\begin{array}{l}\text { b) Negative } \\
\text { Frequency }(\%)\end{array}$} & $\begin{array}{l}\text { a) }+ \text { b) } \\
\text { Frequency } \\
(100 \%)\end{array}$ \\
\hline \multicolumn{6}{|c|}{ 2.2 Pointed to one of the following political newcomers (in all three answers at least once) } \\
\hline \multicolumn{6}{|c|}{ A) The four most often mentioned newcomers: } \\
\hline Hung Tzu-yung & 434 & $(78.3)$ & 120 & $(21.7)$ & 554 \\
\hline Ko Wen-je & 417 & $(84.2)$ & 78 & $(15.8)$ & 495 \\
\hline Freddy Lim & 247 & $(78.7)$ & 67 & $(21.3)$ & 314 \\
\hline \multirow{2}{*}{ Huang Kuo-chang } & 134 & $(80.2)$ & 33 & $(19.8)$ & 167 \\
\hline & 1232 & $(80.5)$ & 298 & $(19.5)$ & 1530 \\
\hline B) Other newcomers & 143 & $(78.6)$ & 39 & $(21.4)$ & 182 \\
\hline \multicolumn{6}{|l|}{ 3. Gender: } \\
\hline Male & 489 & $(74.8)$ & 165 & $(25.2)$ & 654 \\
\hline \multirow[t]{2}{*}{ Female } & 570 & $(76.3)$ & 177 & $(23.7)$ & 747 \\
\hline & 1059 & $(75.6)$ & 342 & $(24.4)$ & 1401 \\
\hline \multicolumn{6}{|l|}{ 4. Age: } \\
\hline $20-29$ & 166 & $(85.1)$ & 29 & $(14.9)$ & 195 \\
\hline $30-39$ & 221 & $(85.3)$ & 38 & $(14.7)$ & 259 \\
\hline $40-49$ & 273 & $(78.2)$ & 76 & $(21.8)$ & 349 \\
\hline $50-59$ & 226 & $(68.7)$ & 103 & $(31.3)$ & 329 \\
\hline \multirow[t]{2}{*}{60 and above } & 163 & $(65.2)$ & 87 & $(34.8)$ & 250 \\
\hline & 1049 & $(75.9)$ & 333 & $(24.1)$ & 1382 \\
\hline \multicolumn{6}{|l|}{ 5. Occupation: } \\
\hline Managers & 208 & (73.5) & 75 & $(26.5)$ & 283 \\
\hline Professionals & 116 & $(81.1)$ & 27 & $(18.9)$ & 143 \\
\hline Staff members & 203 & $(83.9)$ & 39 & $(16.1)$ & 242 \\
\hline Services & 25 & $(71.4)$ & 10 & $(28.6)$ & 35 \\
\hline $\begin{array}{l}\text { Agriculture, forestry, animal } \\
\text { husbandry and fishery }\end{array}$ & 24 & $(75.0)$ & 8 & $(25.0)$ & 32 \\
\hline Laborers/Workers & 191 & $(76.1)$ & 60 & $(23.9)$ & 251 \\
\hline Students & 45 & $(78.9)$ & 12 & $(21.1)$ & 57 \\
\hline Military & 2 & $(40.0)$ & 3 & $(60.0)$ & 5 \\
\hline Homemaker & 123 & $(71.5)$ & 49 & $(28.5)$ & 172 \\
\hline Unemployed & 27 & $(84.4)$ & 5 & $(15.6)$ & 32 \\
\hline Retired & 80 & $(61.1)$ & 51 & $(38.9)$ & 131 \\
\hline \multirow[t]{2}{*}{ Others* } & 1 & $(33.3)$ & 2 & $(66.7)$ & 3 \\
\hline & 1045 & $(75.4)$ & 341 & $(24.6)$ & 1386 \\
\hline
\end{tabular}




\begin{tabular}{|c|c|c|c|c|c|}
\hline & \multicolumn{2}{|c|}{$\begin{array}{l}\text { a) Positive } \\
\text { Frequency (\%) }\end{array}$} & \multicolumn{2}{|c|}{$\begin{array}{l}\text { b) Negative } \\
\text { Frequency }(\%)\end{array}$} & $\begin{array}{l}\text { a) }+ \text { b) } \\
\text { Frequency } \\
(100 \%)\end{array}$ \\
\hline \multicolumn{6}{|c|}{ 6. The party of the candidate for which the respondent voted (in a geographical district): } \\
\hline $\begin{array}{l}\text { Party in the } 9^{\text {th }} \text { LY belonging to the } \\
\text { Pan-Blue camp }\end{array}$ & 193 & $(59)$ & 134 & $(41)$ & 327 \\
\hline $\begin{array}{l}\text { Party in the } 9^{\text {th }} \text { LY belonging to the } \\
\text { Pan-Green camp }\end{array}$ & 430 & $(88.5)$ & 56 & $(11.5)$ & 486 \\
\hline Did not vote & 179 & $(73.1)$ & 66 & $(26.9)$ & 245 \\
\hline \multirow[t]{2}{*}{ Parties \& Independents not in the $9^{\text {th }}$ LY } & 38 & $(82.6)$ & 8 & $(17.4)$ & 46 \\
\hline & 840 & $(76.1)$ & 264 & $(23.9)$ & 1104 \\
\hline \multicolumn{6}{|c|}{$\begin{array}{l}\text { 7. Satisfaction with domestic political parties when it } \\
\text { comes to solving the important social problems: }\end{array}$} \\
\hline Very dissatisfied & 306 & $(68.9)$ & 138 & $(31.1)$ & 444 \\
\hline Dissatisfied & 513 & $(78.1)$ & 144 & $(21.9)$ & 657 \\
\hline Satisfied & 161 & $(80.1)$ & 40 & (19.9) & 201 \\
\hline \multirow[t]{2}{*}{ Very satisfied } & 14 & $(82.4)$ & 3 & $(17.6)$ & 17 \\
\hline & 994 & $(75.4)$ & 325 & $(24.6)$ & 1319 \\
\hline \multicolumn{6}{|c|}{$\begin{array}{l}\text { 8. Satisfaction with the level of attention given by domestic political } \\
\text { parties to young people. The parties are: }\end{array}$} \\
\hline $\begin{array}{l}\text { Very unconcerned about the problems of } \\
\text { young people }\end{array}$ & 220 & $(71.4)$ & 88 & $(28.6)$ & 308 \\
\hline Unconcerned & 441 & $(77.5)$ & 128 & $(22.5)$ & 569 \\
\hline Concerned & 302 & $(79.3)$ & 79 & $(20.7)$ & 381 \\
\hline \multirow[t]{2}{*}{ Very concerned } & 35 & $(64.8)$ & 19 & $(35.2)$ & 54 \\
\hline & 998 & $(76.1)$ & 314 & $(23.9)$ & 1312 \\
\hline \multicolumn{6}{|l|}{ 9. Views on citizens' political participation: } \\
\hline Most supportive of political participation & 497 & $(81.5)$ & 113 & $(18.5)$ & 610 \\
\hline Supportive & 377 & $(73.5)$ & 136 & $(26.5)$ & 513 \\
\hline Against political participation & 115 & $(73.2)$ & 42 & $(26.8)$ & 157 \\
\hline \multirow[t]{2}{*}{ Strongly against } & 44 & $(57.9)$ & 32 & $(42.1)$ & 76 \\
\hline & 1033 & $(76.2)$ & 323 & $(23.8)$ & 1356 \\
\hline \multicolumn{6}{|l|}{ 10. Views on democracy: } \\
\hline $\begin{array}{l}\text { Regardless of the situation, democracy is } \\
\text { the best system }\end{array}$ & 648 & $(81.1)$ & 151 & $(18.9)$ & 799 \\
\hline \multirow{2}{*}{$\begin{array}{l}\text { Under certain circumstances, an autho- } \\
\text { ritarian political system would be better } \\
\text { than democracy }\end{array}$} & 284 & $(66.5)$ & 143 & $(33.5)$ & 427 \\
\hline & 932 & $(76.0)$ & 294 & $(24.0)$ & 1226 \\
\hline
\end{tabular}

Notes: ${ }^{\star}$ Others: Those who have no formal occupation but have an income or those who have never been employed. 


\section{Perception of political newcomers and respondents' social profiles}

Social profiles of Taiwanese who regard political newcomers positively (gender, age and occupation)

As shown in Table 1, the great majority of respondents who disclosed their opinions on the impact of newcomers' participation in Taiwan's political process (81.4\%) declared it "positive," i.e., $75.6 \%$ of responses (1,059 out of 1,401 ), with the percentage of male and female respondents nearly equal at $74.8 \%$ and $76.3 \%$ respectively (Question 3). In terms of age distribution, it is evident that the younger generation of Taiwanese is more supportive of the newcomers than is the older one (Question 4). The respondents in their twenties and thirties are the most approving of the newcomers $(85.1 \%$ and $85.3 \%$ respectively), and the decline in higher age groups is steady: $78.2 \%$ of those who view newcomers positively are in their forties; $68.7 \%$ in their fifties; and $65.2 \%$ are older than 60 (Table 1). Turning to the relationship between the respondents' occupation and attitudes toward the newcomers (Question 5), the most supportive of the latter are the unemployed (84.4\%) followed by staff members (83.9\%) and professionals (81.1\%), including researchers, medical technicians, accountants, teachers, judges, lawyers, religious workers, artists, writers, engineers and sport professionals. Contrary to our hypothesis, students do not constitute the group most supportive of the newcomers, and with $78.9 \%$ of positive answers are only the fourth most supportive group among the total 12 occupational categories.

Social profile of Taiwanese who regard political newcomers negatively (sex, age and occupation)

A total of 342 respondents, who disclosed their opinions on the impact of newcomers' participation in the political process on Taiwanese society, deemed it negative, that is, $24.4 \%$ of 1,401 responses. The percentage of male respondents expressing negative opinions (25.2\%) was slightly higher than that of females (23.7\%). With regard to age, as shown in Table 1, negative responses showed a steady increase relative to respondents' ages, i.e. the higher the age bracket, the greater the percentage of negative responses ( $40-49$ years old, $21.8 \% ; 50-59,31.3 \%$; respondents in their sixties and above, 34.8\%), with one exception of the two youngest groups where the percentage of negative 
responses was similar and for ages 20-29, and 30-39, at $14.9 \%$ and, $14.7 \%$, respectively. Of those who take a dim view of political newcomers' impact on Taiwanese society, negative responses from people in their twenties and thirties were less than half of those given by individuals in the highest age cohort (60 and above), i.e. $14.9 \%$ and $14.7 \%$, respectively, versus $34.8 \%$. With respect to occupation, one of the groups least favorable toward the newcomers were retired respondents, with $38.9 \%$ negative answers, compared to those who were most supportive of newcomers, that is, staff members (non-managerial and non-professional office workers), and the unemployed, who expressed negative views in only $16.1 \%$ and $15.6 \%$ of responses.

\section{Perception of political newcomers in the context of the 2016 parlia- mentary elections}

Opinions of newcomers' participation in electoral politics differ according to respondents' political preferences. According to the survey, in the 2016 parliamentary elections, Taiwanese who voted for candidates from the geographical constituencies (single-member districts, SMD) belonging to two political parties - the Trees Party and the NPP - and the independent candidates, held the most positive views of newcomers (100\% each). However, as only two respondents voted for Trees Party candidates and 14 for the independent candidates, these results cannot be treated as representative. NPP voters' support of newcomers (28 respondents had a positive view of the newcomers) should not be surprising, as this party's vanguard consists of political newcomers, and respondents viewed the NPP itself as a "newcomer."

In light of these findings, the distribution of answers among supporters of the two biggest parties in the LY, the DPP and KMT, as well as the five other political parties that secured seats in the $9^{\text {th }} \mathrm{LY}$, merit analysis. The survey results show that DPP voters are far more supportive of newcomers (87.8\%) than are KMT voters (56.9\%). The DPP's openness toward students and activists during and after the Sunflower Movement stands in stark contrast to KMT elitism and the relative lack of young politicians within the party ranks. Therefore, the relatively high percentage of negative attitudes toward newcomers among the KMT supporters (43.1\% versus $12.2 \%)$ might also be attributed to the respondents' age. Similarly, after the parties in the $9^{\text {th }}$ LY were divided into two opposing groups - the Pan-Blue camp, consisting 
of the KMT, the People First Party (PFP, Qinmin Dang 親民黨), and the Non-Partisan Solidarity Union (NPSU, Wu Dang Tuanjie Lianmeng 無黨團 結聯盟); and the Pan-Green camp which included the DPP and NPP - it becomes clear that the Pan-Green camp electorate is much more supportive of the newcomers than the respondents who voted for Pan-Blue candidates $(88.5 \% \text { versus } 59 \% \text {, see table 1, Question } 6)^{20}$.

\section{Perception of political newcomers in the context of respondents' satisfaction with political parties, views on participation, and democracy}

The analysis of the survey responses (Questions 1 and 7) indicates that correlation between satisfaction with political parties in a government and perceptions of newcomers indicate a trend. The more dissatisfied are Taiwanese with their parties, the more unfavorable are toward the newcomers. This finding goes against our hypothesis, which assamed that dissatisfaction with the current situation in politics would make voters more susceptible to new ideas introduced by the newcomers. Respondents who are "very satisfied" or "satisfied" with domestic parties' handling of social problems are the most positive, and are slightly more positive toward newcomers than average (77.4\%), at $82.4 \%$ and $80.1 \%$, respectively (see Table 1 ), and their views are similar to each other. Those who are "very dissatisfied" with domestic parties are more sceptical of political novices' participation in politics (31.1\%) than any other group. Their negative view of newcomers is around $10 \%$ higher than the percentage of negative responses expressed by the other groups, as the percentage of negative opinions held by "dissatisfied," "satisfied" and "very satisfied" respondents were $21.9 \%, 19.9 \%$, and $17.6 \%$, respectively. In summary, even though an overwhelming majority of Taiwanese voters are displeased with current political parties when it comes to solving social problems (30.7\% were "very dissatisfied" and $44.5 \%$ were "dissatisfied," while only $14.2 \%$ were "satisfied" and 1.4\% "very satisfied") (Question 7), this dissatisfaction does not necessarily fuel their sympathy towards the newcomers.

20 The NPP is generally perceived to be and describes itself as a "third force." However, due to ideological similarities and close cooperation with the DPP in the 2016 elections, it is classified here as 'Pan-Green'. 
Taiwanese also expressed dissatisfaction with the level of attention given by domestic political parties to young people's problems. According to $20.5 \%$ of respondents, the parties are very unconcerned"; $38.9 \%$ rated the parties "unconcerned," 26.6\% "concerned," and 3.9\% "very concerned" (Question 8). The hypothesis that citizens who are more dissatisfied with the level of attention given to young people's problems by the parties would tend to be more positive about the impact of political newcomers than would those who expressed satisfaction was not borne out by the data. On the contrary, among Taiwanese who believe that political parties are concerned with youth's problems, the percentage of those who approved of newcomers was the highest $(79.3 \%)$, contrasting sharply with those who viewed them negatively (20.7\%). Moreover, the more critical respondents were of domestic parties' stances on youth issues, the more negative were their attitudes toward newcomers, as those who felt that mainstream parties are "unconcerned" or "very unconcerned", expressed negative views of newcomers, at $22.5 \%$ and $28.6 \%$ (see Table 1). These results could have indicated a positive correlation between discontent with political parties' concern for youth issues and negative attitudes toward newcomers if the group most satisfied with the level of attention given to young people's problems ("very concerned") had followed this trend and displayed a lower percentage of negative attitudes towards the newcomers than all the other groups. However, as high as 35.2\% of those who indicated that Taiwanese political parties are "very concerned" with young people's problems take a dim view of newcomers to politics; this was the group that registered the highest level of dissatisfaction with the newcomers. Therefore, this relationship does not indicate a trend.

The findings also suggest that increased acceptance of newcomers is characteristic of Taiwanese who are the most supportive of political participation as expressed in answers to Question 9. This conclusion confirms the hypothesis. The survey assessed respondents' views on citizens' political commitment, inter alia, according to their answers to the following statement: Some people say that everyone should mind his/her own business and should not inquire too deeply into public affairs (Question 9). Responses to this question - measured by the answers "strongly disagree" (the group most supportive of the citizens' political involvement), "disagree" (the group expressing support), "agree" (the group against the citizens' involvement in 
politics), "strongly agree" (the group strongly against the citizens' political participation), or "no response" - indicate support for broad and open citizen participation in politics at $78 \%$. The answers correlate with the division of respondents' opinions on whether newcomers' participation in politics has a positive or negative impact on Taiwanese society. Those who strongly disagree with citizen political involvement see the novices in the most unfavorable light (42.1\%). Disapproval of the novices gradually decreases among respondents as their support for wider political commitment on the part of Taiwanese citizens increases: $26.8 \%$ were opposed to citizen participation while $26.5 \%$ supported it. It reached its lowest level with respondents most in favor of citizen participation (18.5\%), which is the group most supportive of newcomers (81.5\% of positive answers in this group as opposed to $73.5 \%$, $73.2 \%$ and 57.9 for supporters of participation, those who oppose it, and those who strongly oppose it, respectively).

The respondents were also asked to share their opinions on what they deemed to be an appropriate political system: Some say that regardless of the situation, democracy is the best system; others say that under certain circumstances, an authoritarian political system would be better than democracy (Question 10). Comparison of these answers with the same respondents' opinions of the newcomers (see Table 1) demonstrated that Taiwanese who feel positively about political newcomers' impact on society $(81.1 \%)$ expressed a greater support for democracy than those who felt that "under certain circumstances an authoritarian political system is better than democracy" (66.5\%).

\section{Predictors of positive attitudes toward the newcomers}

Having compared the voters with positive and negative attitudes toward the political novices from a bivariate perspective, now move to a statistical regression model in order to present more rigorous analysis of the factors that may help to differentiate the two attitudes.

The identification of Ko Wen-je as a political newcomer (as expressed in answers to Question 2), political sympathies as manifested in decisions to vote for candidates from a particular political camp - including Pan-Blue or Pan-Green (Q6) - attitudes toward democracy (Q10), and opinions about 
the political participation of citizens (Q9) all constitute significant predictors of opinion about the political novices (see Table 2). With respect to demographic characteristics, only respondents' age (Q4) is significantly related to the answers disclosing opinions of newcomers. However, satisfaction with the domestic political parties when it comes to solving important social problems (Q7), opinions about domestic political parties' concern with the young people's problems (Q8), and demographic characteristics including gender (Q3) and occupation (Q5) are not significant determinants of respondents' opinions of the newcomers.

To better understand the significant predictors of positive attitudes toward the political newcomers among the Taiwanese voters, I looked into the logistic regression results for every answer to the statistically significant survey questions.

Table 2. Logistic Regression Estimates for Positive Opinions about the Political Newcomers - Political Attitudes and Demographic Characteristics

\begin{tabular}{|c|c|c|c|c|c|}
\hline & \multicolumn{2}{|c|}{ Coefficient } & $\begin{array}{l}\text { Std. } \\
\text { Error }\end{array}$ & OR & $95 \% \mathrm{CI}$ \\
\hline \multicolumn{6}{|c|}{$\begin{array}{l}\text { In recent years, numerous "political newcomers" have run for public office. Who would you } \\
\text { consider a political newcomer? (list 1-3 newcomers) }\end{array}$} \\
\hline a) Hung Tzu-yung & -.00 & & .25 & 1.00 & {$[.61,1.62]$} \\
\hline b) Ko Wen-je & .50 & * & .24 & 1.66 & {$[1.04,2.67]$} \\
\hline c) Freddy Lim & -.31 & & .22 & .73 & {$[.48,1.13]$} \\
\hline d) Huang Kuo-chang & .14 & & .28 & 1.15 & {$[.68,2.02]$} \\
\hline e) NPP & -.16 & & .40 & 1.85 & {$[.40,1.94]$} \\
\hline f) Other political newcomers & -.14 & & .31 & .87 & {$[.47,1.58]$} \\
\hline \multicolumn{6}{|l|}{ Gender } \\
\hline a) Male - reference level & & & & & \\
\hline b) Female & .26 & & .18 & 1.29 & {$[.91,1.84]$} \\
\hline \multicolumn{6}{|l|}{ Age } \\
\hline \multicolumn{6}{|l|}{ a) 20-29- reference level } \\
\hline b) $30-39$ & .02 & & .34 & 1.02 & {$[.52,2.00]$} \\
\hline c) $40-49$ & -.37 & & .32 & .69 & {$[.36,1.27]$} \\
\hline d) $50-59$ & -.63 & . & .33 & .53 & {$[.28, .99]$} \\
\hline e) 60 and above & -.61 & . & .37 & .54 & {$[.26,1.10]$} \\
\hline
\end{tabular}




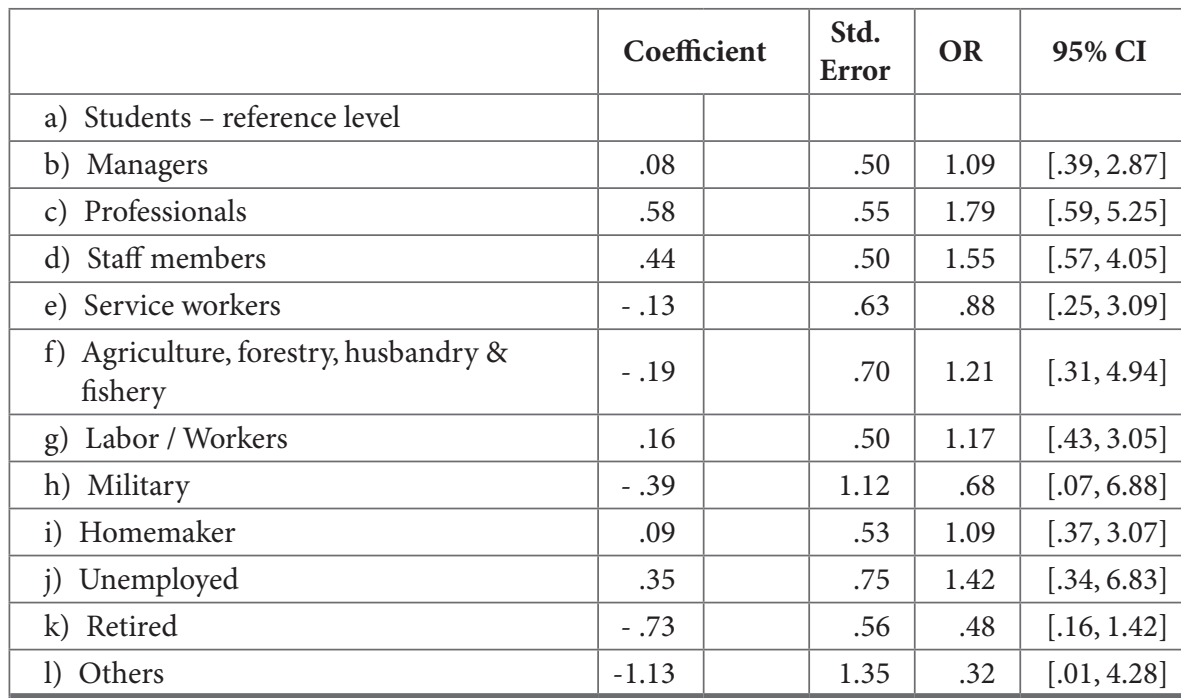

Which party's candidate in your electoral district did you vote for in the parliamentary elections (open question)?

\begin{tabular}{|l|r|r|r|r|r|}
\hline a) Pan-Blue Parties in the $9^{\text {th }} \mathrm{LY}$ & -.54 & $*$ & .23 & .58 & {$[.37, .90]$} \\
\hline b) Pan-Green in the $9^{\text {th }} \mathrm{LY}$ & .78 & $* *$ & .25 & 2.18 & {$[1.33,3.59]$} \\
\hline $\begin{array}{l}\text { c) Other parties for which the respondents } \\
\text { voted }\end{array}$ & .42 & & .51 & 1.52 & {$[.59, .4 .44]$} \\
\hline d) Did not vote & -.19 & & .26 & .82 & {$[.50,1.36]$} \\
\hline
\end{tabular}

In general, are you satisfied with domestic political parties when it comes to solving important social problems?

a) Very dissatisfied - reference level

\begin{tabular}{|l|r|r|r|r|r|}
\hline b) Dissatisfied & .19 & & .19 & 1.21 & {$[.84,1.75]$} \\
\hline c) Satisfied & -.01 & & .28 & .99 & {$[.58,1.71]$} \\
\hline d) Very satisfied & -.30 & & .76 & .74 & {$[.18,3.88]$} \\
\hline
\end{tabular}

In general, do you believe that domestic political parties are unconcerned with young people's problems?
a) Strongly disagree - reference level

\begin{tabular}{|l|r|r|r|r|r|}
\hline b) Disagree & .19 & & .21 & 1.21 & {$[.80,1.82]$} \\
\hline c) Agree & .16 & & .24 & 1.17 & {$[.74,1.86]$} \\
\hline d) Strongly agree & -.36 & & .46 & 1.43 & {$[.60,3.67]$} \\
\hline
\end{tabular}

Some people say that everyone should mind his/her own business and should not inquire too much into the public affairs. What is your opinion on this topic?
a) Strongly disagree - reference level
b) Disagree (supportive of political participation)
c) Agree (against political participation)

\begin{tabular}{|l|l|l|l|r|}
\hline-.46 & $\star$ & .18 & .63 & {$[.44, .90]$} \\
\hline-.48 &. & .27 & .62 & {$[.36,1.05]$} \\
\hline
\end{tabular}




\begin{tabular}{|c|r|r|r|r|r|}
\hline & \multicolumn{2}{|c|}{ Coefficient } & $\begin{array}{c}\text { Std. } \\
\text { Error }\end{array}$ & OR & 95\% CI \\
\hline $\begin{array}{l}\text { d) Strongly agree (strongly against } \\
\text { participation) }\end{array}$ & -1.18 & $* * *$ & .33 & .31 & {$[.16, .60]$} \\
\hline $\begin{array}{l}\text { 10. Some people say that regardless of the situation, democracy is the best system of gover- } \\
\text { nment; others say that under certain circumstances, an authoritarian political system would } \\
\text { be better than democracy? With which statement do you agree? }\end{array}$ & [.36, \\
\hline a) Regardless of the situation, democracy is the best system - reference level \\
\hline $\begin{array}{l}\text { c) Under certain circumstances, an } \\
\text { authoritarian political system would be } \\
\text { better than democracy }\end{array}$ & -.69 & $* * *$ & .16 & .50 & \\
\hline
\end{tabular}

Note: $\mathrm{OR}=$ odds ratio; $\mathrm{CI}=$ confidence interval;

Significance codes: ${ }^{* *} \mathrm{p}<.001$ level, ${ }^{* *} \mathrm{p}<.01$ level, ${ }^{\star} \mathrm{p}<.05$ level, $. \mathrm{p}<.1$ level.

Number of observations in the model -1401

Akaike Information Criterion (AIC): 1069.4

The probability of a positive outlook on novices grew by $66 \%$ among respondents who pointed out to Ko Wen-jie in Q2 as at last one of the three newcomers in comparison to those who did not name him at all. Therefore, those who recognize Ko as a newcomer are noticeably positive about the novices. Given that $43 \%$ of all the respondents who expressed an opinion about the newcomers listed Ko first (425 out of 984 respondents, see Table 1 ), the great number of respondents may see newcomers through the prism of Ko, and their attitude toward the Taipei mayor was decisive for their general outlook on newcomers. However, this assumption necessitates further inquiry. That the results are not significant for any of the other most often mentioned newcomers whose personal stories are widely recognized in society leaves us without an answer to whether the prospect of being viewed positively grows for the four novices distinguished by their personal stories compared to all the other novices.

When it comes to the respondents' ages, the chances of positive outlooks on newcomers decrease significantly for the two oldest cohorts (i.e. 50-59 and 60 and above), in comparison with the youngest group, the 20-29 year-olds. (Q4, $\beta=-.63$ for the respondents between 50 and 59 and $\beta=-.61$ for those above 60 years old). In comparison with the youngest group of respondents, the odds of positive attitudes toward newcomers decrease by $47 \%$ for $50-59$ year-olds, and by $46 \%$ for those over 60 (with 95\% CI [.28, .99] and [.26, 
1.10], respectively). The oldest respondents are, therefore, the least positive about the newcomers when compared with the youngest cohort.

Turning to the comparison of Pan-Blue with Pan-Green voters' attitudes toward the newcomers (concerning only Pan-Blue and Pan-Green parties that won seats in the $9^{\text {th }} \mathrm{LY}$ ), the decision to vote in the geographical district for the candidates from the parties belonging to the Pan-Blue camp decreased the odds of a positive attitude toward the newcomers by $42 \%$ in comparison with the electorate of the other parties, including the respondents who voted for the Pan-Green camp parties that were elected to the $9^{\text {th }} \mathrm{LY}$, the parties that did not win seats in the election, and those who did not vote.

In turn, the decision to vote for the parties of the Pan-Green camp elected to the $9^{\text {th }}$ LY considerably increased the probability of positive attitudes toward the newcomers (by $118 \%, \mathrm{OR}=2.18$ for the respondents voting for Pan-Green parties, that secured seats in the $9^{\text {th }} \mathrm{LY}$ in comparison with the respondents voting for Pan-Blue parties elected to the $9^{\text {th }} \mathrm{LY}$, the parties, which did not secure seats in the $9^{\text {th }} \mathrm{LY}$ and the respondents, who did not vote).

Respondents' opinions as expressed in answers to Q9 about the political participation is negatively related to the positive opinion about the newcomers $(\beta=-.46$; for those who "disagree" $\beta=-.48$; for those who 'agree'; $\beta=-1.18$; for those who "strongly agree" with the statement that "everyone should mind his/her own business and should not inquire too much into the public affairs" in comparison to the group of the respondents, who "strongly disagree" (See Table 2). It means, that those who expressed the strongest support for citizens' inquiries into public affairs, i.e. "strongly disagree" with the statement in the question, are also the most positive about the newcomers and with the decline in support for citizens' engagement in politics, the chances for positive views of the newcomers deteriorates. In other words, the odds of positive attitudes toward newcomers diminish by $37 \%, 38 \%$ and $69 \%$ as support for political activism decreases (where 95\% CI [.44, .90], [.36, $1.05]$ and $[.16, .60]$ respectively) in comparison with the group that showed the greatest support for citizen participation in the political process.

The probability of positive views of newcomers is lower among those who under certain circumstances see an authoritarian political system as superior to democracy than among the unconditional supporters of democracy (Q10) by $50 \%$ with $95 \%$ CI $[.36, .69]$. 


\section{Discussion}

In general, Taiwanese approve political newcomers, as $75.6 \%$ of respondents, who revealed their opinion about the newcomers described their impact as positive, while only $24.4 \%$ called it as negative. $89.4 \%$ of survey responses in the first place pointed only to four individuals: Hung Tzu-yung, Ko Wen-je, Freddy Lim and Huang Kuo-chang (listed in the order from the most often to least often mentioned). These neophytes share a common characteristic - thanks to their personal stories, each of them enjoyed island-wide recognition well before becoming involved in electoral politics. Although Hung, Ko, Lim, and Huang's personal stories differ, they have greatly contributed to the candidates' fame, popularity, and electoral success. This study examined attitudes toward political newcomers with respect to respondents' demographic characteristics and political preferences.

The most supportive of the newcomers were those who recognized Ko Wen-je as a political newcomer in comparison to those who did not name him at all. Moreover, the probability of a positive outlook on novices grew by $66 \%$ with respondents who pointed to Ko at least as one of the three newcomers in comparison to those who did not point to him at all.

This research confirms that younger Taiwanese are generally more positive toward political newcomers than are older members of society. The youngest respondents, i.e. those in the 20-29 age bracket, the majority of whom voted for the first time in 2016, as well as those between 30 and 39 years old view newcomers the most positively $(85.1 \%$ and $85.3 \%$ respectively), whereas all other age groups' approval of newcomers, though still quite high, trended downwards. In comparison with the youngest group of respondents, the odds of positive attitudes toward newcomers when it comes to gender of the respondents, support for the newcomers among males and females is very similar ( $74.8 \%$ and $76.3 \%$ respectively), decreasing by $47 \%$ for the $50-59$ year-olds and by $46 \%$ for those over 60 years old and more. Turning to the relationship between the respondents' occupation, and attitudes toward the newcomers, the hypothesis that assumed the highest support is among students did not prove to be true. The support for the novices is the highest among the unemployed (84.4\%), followed by staff members (83.9\%), and professionals (81.1\%), including researchers, medical 
technicians, accountants, teachers, judges, lawyers, religious workers, artists, writers, engineers and sport professionals, while students, with $78.9 \%$ of positive answers constitute only the fourth most supportive group among the total 12 occupational categories.

As for political preferences, the findings prove the hypothesis that the electorate of the Pan-Green camp is much more supportive of the newcomers than the respondents who voted for the Pan-Blue candidates. Moreover, the decision to vote in the geographical district for the candidates from the parties belonging to the Pan-Blue camp decreased the odds of positive attitudes toward the newcomers by $42 \%$, while the decision to vote for Pan-Green camp parties considerably increased the probability of positive attitudes $(118 \%)$ toward the newcomers in comparison with other parties' electorates.

The hypothesis predicting a positive trend between citizen discontent with the current political parties and approval of newcomers is erroneous in two instances. In the first instance, the hypothesis stated that dissatisfaction with the parties' performance when it comes to solving important social problems would make voters more susceptible to new ideas introduced by the newcomers. However, the research shows that the more dissatisfied Taiwanese are with their parties, the more unfavorably they viewed the newcomers.

Similarly, the hypothesis suggesting that citizens who are more dissatisfied with the level of attention given to young people's problems by the parties would tend to be more positive about political newcomers' impact than would those who expressed satisfaction was not borne out by the data. On the contrary, among Taiwanese who believe that political parties are concerned with youth's problems, the percentage of those who approved of newcomers was the highest (79.3\%), contrasting sharply with those who viewed them negatively (20.7\%). Moreover, the more critical respondents were of domestic parties' stances on youth issues, the more negative were their attitudes toward newcomers.

The study also demonstrates that increased acceptance of newcomers is a characteristic of Taiwanese who are the most supportive of political participation. Those who strongly disagree with citizen political involvement see the novices in the most unfavorable light (42.1\%). The disapproval of the novices gradually decreased among respondents as their support for wider political commitment on the part of Taiwanese citizens increased, coming 
to $26.8 \%$ for those against the participation, and $26.5 \%$ for those who support participation. It reached its lowest level with the group of respondents most favorable toward the citizen participation (18.5\%), which is also the group most supportive of newcomers. This conclusion is consistent with the hypothesis. Moreover, the relationship between opinions on political participation and attitudes toward the newcomers is statistically significant. The odds of positive attitudes toward newcomers diminish with the decrease in support for political activism.

Taiwanese who expressed a greater support for democracy than those who felt that "under certain circumstances an authoritarian political system is better than democracy" also were more positive about political newcomers' impact on society $(81.1 \%)$ than the latter $(66.5 \%)$. The probability of a positive view of newcomers is lower among those who under certain circumstances see an authoritarian political system as superior to democracy than it is among the unconditional supporters of democracy by a margin of $50 \%$. This finding stands in opposition to the hypothesis, which stated that the supporters of the newcomers do not necessarily see democracy as the best system, since the political debutants are very often seen as various types of outsiders, including outsiders to the political system, who may challenge it.

Nevertheless, the four most popular novices in Taiwan as indicated by the 2016 survey and who constituted the focus of the analysis received DPP support and represented the Pan-Green camp. This finding suggests that the Pan-Green camp, as opposed to the Pan-Blue camp, was able to take advantage of the new trends related to the personalization of politics and the growing demand for personal stories. At the same time, the analysis covered only the candidates from one camp. This partisan bias sets important limits on the findings, which do not shed light on society's attitudes toward newcomers representing different political orientations. 


\section{Appendix: \\ Survey questions and responses}

I. Taiwanese voters' perceptions of newcomers:

1. Has newcomers' participation in politics had a positive or negative impact on Taiwanese society? Response options: a) positive, b) negative, c) no response, including "depends on situation," "no opinion," "don't know," "respondent refused to answer,"

2. In recent years, numerous "political newcomers" have run for public office. Who would you consider a political newcomer (open question, the respondents could list one to three newcomers)?

II. Respondents' demographic characteristics:

3. What gender are you?

4. What is your birthdate?

5 . What is your occupation?

III. Questions designed to obtain a deeper understanding of respondents who have positive or negative attitudes towards the newcomers:

6. Which party's candidate in your electoral district did you vote for in the parliamentary elections (open question)?

7. In general, are you satisfied with domestic political parties when it comes to solving the important social problems? Response options: a) very dissatisfied, b) dissatisfied, c) satisfied, d) very satisfied, e) no response, including "depends on the situation," "no opinion," "don't know," "respondent refused to answer."

8. In general, do you believe that domestic political parties are unconcerned with young people's problems? Response options: a) very unconcerned, b) unconcerned, c) concerned, d) very concerned, e) no response, including "depends on the situation," "no opinion," "don't know," "respondent refused to answer."

9. Some people say that everyone should mind his/her own business and not inquire too deeply into public affairs. What is your opinion on this topic? Response options: a) strongly disagree, b) disagree, c) agree, d) strongly agree, e) no response, including "depends on the situation," "no opinion," "don't know," "respondent refused to answer."

10. Some people say that regardless of the situation, democracy is the best system of government; others say that under certain circumstances, an authoritarian political system would be better than democracy. With which statement do you agree? Response options: a) regardless of the situation, democracy is the best system; b) under certain circumstances, an authoritarian political system would be better than democracy; c) no response, including "depends on the situation," 'no opinion," "don't know," "respondent refused to answer." 
ANNA RUDAKOWSKA, PHD

Department of Global Politics and Economics

Tamkang University

No.180, Linwei Rd., Jiaoxi Township

Yilan County 26247, Taiwan (R.O.C.)

142036@mail.tku.edu.tw

\section{References}

Barr, R.R. (2003). The Persistence of Neopopulism in Peru? From Fujimori to Toledo. Third World Quarterly, 24(6), 1161-1178.

Barr, R.R. (2009). Populists, Outsiders and Anti-Establishment Politics. Party Politics, 15(1), 29-48.

Batto, N.F. (2013). Partisan and Personal Voting in SNTV: A Mixed Logit Model. Journal of Electoral Studies, 12(1), 121-153.

Berry, J.M., Sobieraj, S. (2016). The Outrage Industry: Political Opinion Media and the New Incivility. Oxford: Oxford University Press.

Biography: Wen-je Ko. Taipei City Government. (2016, February 22). Retrieved from: http://english.gov.taipei/ct.asp?xItem $=93397293 \&$ CtNode $=8509 \& m p=100002$

Van der Blom, H. (2010). Cicero's Role Models. The Political Strategy of Newcomer. Oxford/ New York: Oxford University Press.

Boguszewski, R. (2015). Kim sa wyborcy Pawła Kukiza? Komunikat z Badań CBOS [Who are Pawel Kukiz'voters? The communication from the CBOS' analysis], CBOS, 86, $1-15$.

Bunker, K., Navia, P. (2013). Latin American Political Outsiders, Revisited: The Case of Marco Enríquez-Ominami in Chile, 2009. Journal of Politics in Latin America, 5(2), 3-35.

Canon, D.T. (1990). Actors, Athletes, and Astronauts. Political Amateurs in the United States Congress. Chicago: University of Chicago Press.

Copper, J.F. (1998). Taiwan's mid-1990s Elections: Taking the Final Steps to Democracy. Westport: Praeger Publishers.

Cowley, P.P. (2012). Arise, Novice Leader! The Continuing Rise of the Career Politician in Britain. Politics, 32(1), 31-38.

Duch, R.M., Stevenson, R.T. (2008). The Economic Vote: How Political And Economic Institutions Condition Election Results. New York: Cambridge University Press.

Dugas, J.C. (2003). The Emergence of Neopopulism in Colombia? The Case of Alaro Uribe. Third World Quarterly, 24(6), 1117-1136.

Ellner, S. (2003). The Contrasting Variants of the Populism of Hugo Chávez and Alberto Fujimori. Journal of Latin American Studies, 35(1), 139-162.

English Oxford Living Dictionaries, Oxford University Press. Retrieved from: https:// en.oxforddictionaries.com/definition/newcomer 
Fell, D. (2005). Measuring and Explaining Party Change in Taiwan: 1991-2004. Journal of East Asian Studies, 5(1), 105-133.

Fell, D. (2005). Party Politics in Taiwan. Party Change and the Democratic Evolution of Taiwan 1991-2004. London: Routledge.

Fell, D. (2014). Measuring and Explaining the Electoral Fortunes ff Small Parties in Taiwan's Party Politics. Issues \& Studies, 50(1), 153-188.

Fell, D. (2016). Small Parties in Taiwan's 2016 National Elections: A Limited Breakthrough? American Journal of Chinese Studies, 23(1), 41-58.

Ferguson, N. (2016). The Populism Bomb. The Trump Phenomenon Explained. Hoover Digest, 3, Summer, 22-27.

Hitlin, R.A., Jackson, J.S. (1977). On Amateur and Professional Politicians. The Journal of Politics, 39(3), 786-793.

Hu, Y.C. (2015, November 23). A Young Woman's March towards the Legislative Yuan: Interview with Hung Tzu-Yung (Hong Ci-yong). New Bloom. Retrieved from: https:// newbloommag.net/2015/11/23/hung-tzu-yung-eng/

Jamieson, K. (1984). Packaging the Presidency. Oxford: Oxford University Press.

Jou, W. (2009). Electoral Reform and Party System Development in Japan and Taiwan: A Comparative Study, Asian Survey, 49(5), 759-785.

Kenney, C.D. (1998). Anti-politicians, Outsiders and Party Politics: New Conceptual Strategies and Empirical Evidence from Peru. Party Politics, 4(1), 57-75.

King, A. (2002). The Outsider as Political Leader: The Case of Margaret Thatcher. British Journal of Political Science, 32(3), 435-454.

Liao, D.C. (2010). Changes in Legislative Career Types and the Development Orientation of Democracy: A Study of Taiwan's Legislative Yuan from the Second Term to the Seventh Term (in Chinese). Soochow Journal of Political Science, 18(2), 49-96.

Mancini, P., Swanson, D (1996). Politics, Media, and Modern Democracy: Introduction. In: D. Swanson, P. Mancini (Eds). Politics, media, and modern democracy (1-26). New York: Praeger.

Marshall, P.D. (1997). Celebrity and Power: Fame in Contemporary Culture: U of Minnesota Press.

Merriam-Webster, Online Dictionary. Retrieved from: https://www.merriam-webster.com Meyer, T., Hinchman, L.P. (2002). Media Democracy: How Media Colonize Politics. Cambridge: Polity.

Mutz, D.C. (2015). In-Your-Face Politics: The Consequences of Uncivil Media. Princeton: Princeton University Press.

Ostiguy, P., Roberts, K.M. (2016). Putting Trump in Comparative Perspective: Populism and the politicization of the sociocultural low. Brown Journal of World Affairs, 23, 1.

Roback, T.H. (1975). Amateurs and Professionals: Delegates to the 1972 Republican National Convention. The Journal of Politics, 37(2), 436-468.

Rudakowska, A., Trojnar, E. (2016). Who is a Political Newcomer? The Taiwanese Voters' Perspective: 2016. Hemispheres, 31(3), 68-78.

Schafferer, C. (2003). The Power of the Ballot Box. Political Development and Election Campaigning in Taiwan. New York: Lexington.

Schedler, A. (1996). Anti-political Establishment Parties. Party Politics, 2(3), 291-312. 
Schmidt, R., Alex-Assensoh, Y.M., Aoki, A.L., Hero, E.R. (2010) Newcomers, Outsiders, and Insiders. Immigrants and American Racial Politics in the Early Twenty-First Century. Ann Arbor: University of Michigan Press.

Street, J. (2004). Celebrity Politicians: Popular Culture and Political Representation. The British journal of politics and international relations, 6(4), 435-452.

Thimsen, A.F. (2010). Populist Celebrity in the Election Campaigns of Jesse Ventura and Arnold Schwarzenegger, The Velvet Light Trap, (65), 44-57.

Tsai, C.H. (2016, March). Political Attitudes and Participation of Young Generation in the National and Local Elections. Paper presented at the Taiwan Symposium: Taiwan Elections in 2016 and Beyond, University of Texas at Dallas. Retrieved from: http://www. utdallas.edu/epps/tds/files/Chia-hung\%20Tsai.pdf

Wen, L. (2015, February 25). NPP Nominates Political Novice. Taipei Times. Retrieved from: http://www.taipeitimes.com/News/taiwan/archives/2015/02/25/2003612201

Wilson, J.Q., Wilson, J.O. (1962). The Amateur Democrat: Club Politics in Three Cities (Vol. 223). University of Chicago Press. 